\title{
Differences in secondary metabolites from leaf extracts of Mikania glomerata Sprengel obtained by micropropagation and cuttings
}

\author{
Silvia H. Taleb-Contini ${ }^{1 *}$, Pierre A. Santos ${ }^{1}$, Rodrigo C.S. Veneziani ${ }^{2}$,Ana Maria S. Pereira ${ }^{3}$, \\ Suzelei C. França ${ }^{3}$, Norberto P. Lopes ${ }^{1}$, Dionéia C.R. Oliveira ${ }^{1}$ \\ ${ }^{1}$ Departamento de Física e Química, Faculdade de Ciências Farmacêuticas de Ribeirão Preto, USP, Avenida do \\ Café s/n, Monte Alegre, 14040-903, Ribeirão Preto, SP, Brasil, \\ ${ }^{2}$ Universidade de Franca, Av. Dr. Armando Salles de Oliveira 201, 14404-600, Franca, SP, Brasil, \\ ${ }^{3}$ Unidade de Biotecnologia, Universidade de Ribeirão Preto, Avenida Costábile Romano 2201, 14096-380, \\ Ribeirão Preto, SP, Brasil
}

\begin{abstract}
RESUMO: "Diferenças nos metabólitos secundários acumulados nos extratos das folhas de Mikania glomerata Sprengel obtidos por micropropagação e estaquia”. A análise realizada por CG dos extratos diclorometânicos das folhas de Mikania glomerata Sprengel mostrou que a planta propagada por estaca produziu cumarina e ácido caurenóico, enquanto que o material micropropagado acumulou apenas cumarina.
\end{abstract}

Unitermos: Mikania glomerata, Asteraceae, micropropagação, estaquia, ácido caurenóico.

\begin{abstract}
GC analysis of the dichloromethane extracts obtained from cultivated specimens of Mikania glomerata Sprengel possibilited to verify that cuttings technique led to production of kaurenoic acid and coumarin while the same results have not been observed by propagation process using in vitro techniques.
\end{abstract}

Keywords: Mikania glomerata, Asteraceae, micropropagation, cuttings, kaurenoic acid.

\section{INTRODUCTION}

Mikania glomerata Sprengel (Asteraceae) is a vine commonly found in the forests of Argentina, Brazil and Paraguai and is popularly known as "guaco", "guaco trepador", "erva de cobra", "cipó - caatinga" and "coração de Jesus" (Gupta, 1995). Its leaf infusions and syrups are widely used in folk medicine for the treatment of respiratory tract diseases (Teske; Tentini, 1997; Pereira et al., 2004; Soares et al., 2006). Mikania glomerata shows many well-known pharmacological activities, among them antimicrobial (Pessini et al., 2003; Amaral et al., 2003; Santos et al., 2003; Duarte et al., 2004), antiinflammatory (Falcão et al., 2005) and antidiarrhoeal (Salgado et al., 2005). The major constituents of the plants are kauran-type diterpenes (Veneziani; Oliveira, 1999) with various biological activities, including antimicrobial activity (Ghisalberti, 1997). Vilegas et al. (1997) reported that the biological activity of Mikania glomerata extracts is due to the presence of the compounds coumarin and kaurenoic acid.

Recently, there has been an increased interest in developing technical subsides for the commercial production of "guaco" (Mikania glomerata Sprengel) by propagation processes (Negrelle, 2001; Pereira et al., 1999) offering a viable tool for mass multiplication and germplasm conservation of rare, endangered and threatened medicinal plants.

The purpose of this study was to investigate the differences in chemical accumulation between leaf extracts of Mikania glomerata obtained by micropropagation and cuttings.

\section{MATERIAL AND METHODS}

\section{Plant material}

Cultivated specimens of Mikania glomerata Sprengel (Compositae) were obtained by propagation by cuttings and in vitro techniques processes as previously described by Pereira et al. (1998) and Pereira et al. (1999). Mikania glomerata Sprengel was collected in October 1994 from a single plant growing in the experimental area of the Universidade de Ribeirão Preto, São Paulo state, Brazil. A voucher specimen is deposited at the herbarium HPMU (Universidade de Ribeirão Preto; accession number 0024). Leaf materials were maintained in a greenhouse for two years and no morphological differences were observed.

Extraction of the plant material and clean-up of the extract

Five $0.2 \mathrm{~g}$ samples of leaves obtained by cutting 

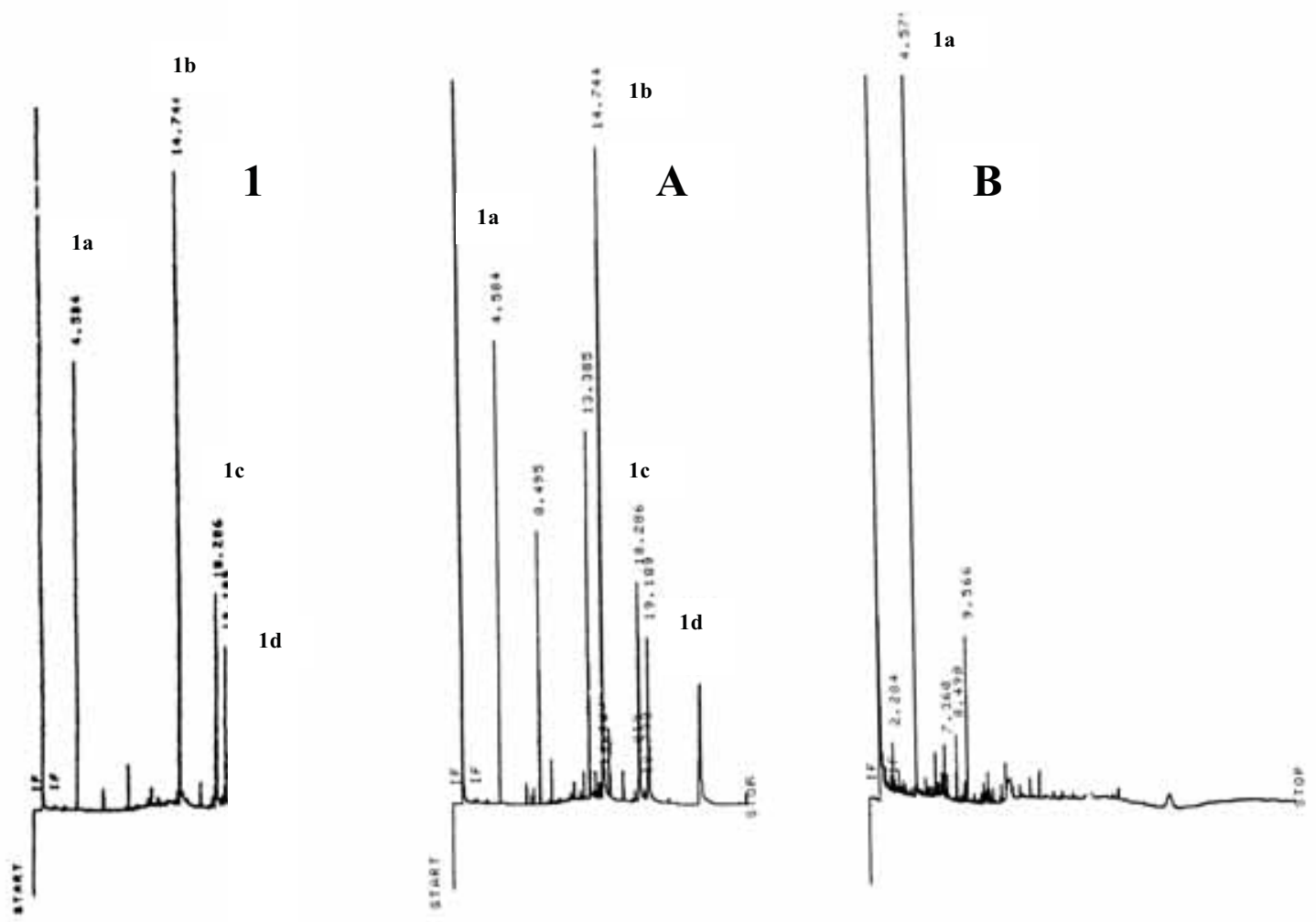

Figure 1. GC analyses of the dichloromethane extract from callus obtained from M. glomerata Sprengel cuttings (A) and leaf explants $(\mathbf{B})$. 1: reference compounds used in GC analyses: 1a: coumarin $(\mathrm{rt}=4.584)$; 1b: ent-kaur-16-en-19oic acid ( $\mathrm{rt}=14.744)$; 1c: 15ß-hydroxy-ent-kaur-16-en-19-oic-acid (rt=18.286); 1d: 17-hydroxy-ent-isokaur-15(16)en-19-oic acid ( $\mathrm{rt}=19.189)$.

(A) or micropropagated leaves (B) were macerated with hexane ( $2 \mathrm{ml}$; room temperature) during $10 \mathrm{~min}$ of sonication. The extract was filtered and eluted through a glass column $(1 \mathrm{~cm}$ i.d) containing $0.2 \mathrm{~g}$ of silica gel (0.063 - $0.200 \mathrm{~mm}$, Merck, Darmstadt, Germany) in the bottom and $0.04 \mathrm{~g}$ of active charcoal (Reagen, Rio de Janeiro, Brazil) on the top. The column was then eluted consecutively with $2 \mathrm{ml}$ of hexane and 3 $\mathrm{ml}$ of dichloromethane. The fractions were combined and evaporated under $\mathrm{N}_{2}$ flux, at room temperature until dryness. These extracts were diluted in $1 \mathrm{ml}$ of a dichloromethane solution $(0.5 \mathrm{mg} / \mathrm{ml})$ of internal standard (goyazensolide).

\section{GC experimental procedure}

The GC analysis was performed using a HewlettPackard 5890 series II instrument equipped with a $30 \mathrm{~m}$ x $0.25 \mu$.m i.d. column coated with methyl silicone $(0.25$ $\mu \mathrm{m}$ film thickness; HP-1 column, supplied by HewlettPackard). $1 \mu \mathrm{L}$ samples were injected using the split mode (1:60 split ratio) with the detector temperature at $300{ }^{\circ} \mathrm{C}$ and the column temperature programmed from $105^{\circ} \mathrm{C}$ to $200{ }^{\circ} \mathrm{C}$ at $13{ }^{\circ} \mathrm{C} / \mathrm{min}$, from $200{ }^{\circ} \mathrm{C}$ to $240{ }^{\circ} \mathrm{C}$ at $6^{\circ} \mathrm{C} / \mathrm{min}$ (remaining at $240{ }^{\circ} \mathrm{C}$ for $20 \mathrm{~min}$.) and from 240 ${ }^{\circ} \mathrm{C}$ to $280{ }^{\circ} \mathrm{C}$ at $10^{\circ} \mathrm{C} / \mathrm{min}$ (remaining at $280{ }^{\circ} \mathrm{C}$ for 10 min.). Hydrogen was used as the carrier gas at an average linear velocity of $39 \mathrm{~cm} / \mathrm{s}$. Data were processed using a Hewlett-Packard HP 3395 integrator. Each determination was carried out at least in triplicate.

\section{RESULTS AND DISCUSSION}

Previous investigation of vegetative propagation by cuttings experiments showed that $M$. glomerata presented positive results for coumarins, steroids, triterpenoids, saponins and volatile acids (Lima, 2002).

In the present study, GC analysis of leaves of Mikania glomerata Sprengel obtained by cutting technique presented coumarin and kaurenoic acid as the major compounds (Figure 1A), as also observed in other wild M. glomerata (Celeghini et al., 2001; Vilegas et al., 1997).

Otherwise, Santos et al. (1999) showed that the phytochemical analysis of the dichloromethane extract from callus obtained from Mikania glomerata Sprengel leaf explants led to the isolation of a mixture of the steroids campesterol, stigmasterol and $\beta$-sitosterol besides 
coumarin. The kaurenoic acid derivative (diterpene) usually found in large amounts in this specie has not been detected (Figure 1B).

According to Pereira et al. (1999), the greatest difficulty in establishing this micropropagation protocol was the high levels of contamination by fungi and bacteria, thus requiring the cultivation of over 5000 explants and a 14 months period to achieve plantlet disinfestation. The mutagenic potential of numerous antibiotics has already been demonstrated, and could be related to the decrease of kaurenoic acid.

On the basis of these data, we can suggest that the efforts for complete elimination of both endogenous and exogenous microorganisms using different classes of antibiotics certainly altered the plant metabolism, resulting in the discrepancy observed in the chemical composition of this micropropagation process.

\section{ACKNOWLEDGMENTS}

This work was supported by FAPESP, CAPES and CNPq, Brazil.

\section{REFERENCES}

Amaral RR, Arcenio Neto F, Carvalho ES, Teixeira LA, De Araújo GL, Sharapin N, Testa B, Gnerre C, Rocha L 2003. Avaliação da atividade IMAO e antibacteriana de extratos de Mikania glomerata Sprengel. Rev Bras Farmacogn 13: 24-27.

Celeghini RMS, Vilegas JHY, Lanças FM 2001. Extraction and quantitative HPLC analysis of coumarin and hydroalcoholic extracts of $M$. glomerata Sprengel ("guaco") leaves. J Braz Chem Soc 12: 706-709.

Duarte MCT, Figueira GM, Pereira B, Magalhães PM, Delarmelina C 2004. Atividade antimicrobina de extratos hidroalcoólicos de espécies da coleção de plantas medicinais CPQBA/UNICAMP. Rev Bras Farmacogn 14(Supl. 1): 6-8

Falcão HS, Lima IO, Santos VL, Dantas HF, Diniz MFFM, Barbosa-Filho JM, Batista LM 2005. Review of the plants with anti-inflammatory activity studied in Brazil. Rev Bras Farmacogn 15: 381-391.

Ghisalberti EL 1997. The biological activity of naturally occurring kaurane diterpenes. Fitoterapia 68: 303325.

Gupta MP1995. Plantas Medicinales Iberoamericanas. CYTED-SECAB, p. 270.

Lima NP 2002. Estaquia semilenhosa e comparação de metabólitos secundários em $M$. glomerata Sprengel e M. laevigata Schultz Bip Ex Baker. Scientia Agrária 3: 113-132.

Negrelle RRB, Doni ME 2001. Efeito da maturidade dos ramos na formação de mudas por meio de estaquia. Horticultura Brasileira 19: 219-222.

Pereira AMS, Menezes AJr, Câmara FLA, França SC 1998. Influence of fertilizer on coumarin content and biomass production in Mikania glomerata Sprengel. Journal of Herbs, Spices \& Medicinal Plants 6: 29-35.

Pereira AMS, França SC, Câmara FLA 1999. Vegetative propagation of Mikania glomerata: Micropropagation and cuttings. Acta Hort 502: 347-352

Pereira RC, Oliveira MTR, Lemos GCS 2004. Plantas utilizadas como medicinais no município de Campos de Goytacazes - RJ. Rev Bras Farmacogn 14 (Supl. 1): $37-40$.

Pessini GL, Holetz FB, Sanches NR, Cortez DAG, Dias-Filho BP, Nakamura CV 2003. Avaliação da atividade antibacteriana e antifúngica de extratos de plantas utilizados na medicina popular. Rev Bras Farmacogn 13(Supl. 1): 21-24.

Salgado HRN, Roncari AFF, Moreira RRD 2005. Antidiarrhoeal effects of Mikania glomerata Spreng. (Asteraceae) leaf extract in mice. Rev Bras Farmacogn 15: 205208.

Santos CR, Arcenio F, Carvalho ES, Lúcio EMRA, Araújo GL, Teixeira LA, Sharapin N, Rocha L 2003. Otimização do processo de extração de própolis através da verificação da atividade antimicrobiana. Rev Bras Farmacogn 13 (Supl. 1): 71-74.

Santos PA, Pereira MAS, França SC, Lopes NP 1999. Esteróides e cumarinas em calos de M. glomerata Sprengel. Braz J Pharm Sci 35: 231-235.

Soares AKA, Carmo GC, Quental DP, Nascimento DF, Bezerra FAF, Moraes MO, Moraes MEA 2006. Avaliação da segurança clínica de um fitoterápico contendo Mikania glomerata, Grindelia robusta, Copaifera officinalis, Myroxylon toluifera, Nasturtium officinale, própolis e mel em voluntários saudáveis. Rev Bras Farmacogn 16: 447-454.

Teske M, Tentini AMM 1997. Compêndio de fitoterapia. Herbarium.

Veneziani RCS, Oliveira DCR 1999. Constituents of Mikania glomerata Sprengel. Biochem Syst Ecol 27: 99-102.

Vilegas JHY, Marchi E, Lanças FM 1997. Determination of coumarin and kaurenoic acid in Mikania glomerata ("guaco") leaves by capillary gas cromatography. Phytochem Analysis 8: 74-77. 